\title{
Nixon buys Plan for Aftack on Cancer
}

by our Washington Correspondent

IN announcing last week to Congress that he would request an additional $\$ 100$ million for cancer research, President Nixon seems to have come close to accepting a plan to set up a NASA-style agency charged with conquering cancer by the same methods used to put men on the Moon. Put forward less than two months ago by a group working outside the usual channels of the scientific advisory apparatus, the plan calls for the National Cancer Institute to be set up as a separate agency outside the National Institutes of Health and endowed with an initial annual budget of $\$ 400$ million.

In his State of the Union message last week President Nixon did not refer specifically to the proposal to set up a separate cancer agency, saying only that he would ask in his budget for the financial year starting this July for an extra $\$ 100$ million "to launch an intensive campaign to find a cure for cancer". He added that he would ask later for whatever additional funds could effectively be used, since "the time has come when the same kind of concentrated effort that split the atom and took man to the Moon should be turned toward conquering this dread disease. Let us make a total national commitment to achieve this goal", the President said. "America has long been the wealthiest nation in the world. Now it is time we became the healthiest nation."

The request for an extra $\$ 100$ million would increase by half the present budget of the National Cancer Institute, raising it much of the way towards the $\$ 400$ million target proposed by the panel of consultants to the Senate Committee on Labor and Public Welfare in its report on December 4 last year (see Nature, 228, 1133; 1970). Another echo of the panel's report in the State of the Union message is $\mathrm{Mr}$ Nixon's comparison of cancer research to the Apollo programme, an analogy which many scientists would regard as of limited truth but which was a major selling point of the Senate panel's report.

The Senate panel's proposal for a blitz on cancer has met with a certain lack of enthusiasm among non-medical scientists, partly because at a time when research funds of all kinds are scarce it was feared that an extra allocation for cancer could only be made at the expense of other fields of research. This objection may fade if, as is reported, the President's budget proposals due to be announced later this week hold increases for scientific research far better than had been expected. Even so, many will remain unconvinced that so much extra money can be spent on cancer research without duplicating or triplicating work in a field that is already overcrowded, particularly in its most promising areas such as virology and immunology. For example the Special Virus Cancer Programme administered by the National Cancer Institute received an extra $\$ 25$ million from Congress last year and an official of the programme said recently he was not having to turn away good ideas for lack of funds.

It is not yet known by what channel the idea of an intensive campaign against cancer reached $\mathrm{Mr}$ Nixon's attention. Dr Edward David, the president's science adviser, was consulted on the proposal, as was the Secretary of Health, Education and Welfare, and both apparently recommended it. The initiative, however, seems more likely to have come from one or other of the Senate panel members, several of whom have close connexions with the Nixon administration. The 26-man panel includes Mr Elmer Bobst, chairman of the Warner-Lambert pharmaceutical company, who is a close friend of Mr Nixon's. Mr Benno Schmidt, the chairman of the panel, is well known to the director of the Office of Management and Budget, Mr George Schultz, and a third member of the panel, Dr Lee Clark of the M. D. Anderson cancer institute in Houston is a friend of Mr John Connally, the new Secretary of the Treasury. In addition $\mathrm{Mr}$ Schmidt and Mr Laurance S. Rockefeller, also a panel member, are heavy contributors to the Republican party funds.

Whether or not Mr Nixon's request is in response to the Senate panel's proposal, those connected with the panel report are encouraged by the unexpected turn of events. Mrs Mary Lasker, a New York millionairess who is credited with considerable influence in winning Senate sponsorship of the resolution setting up the panel, said this week that she was delighted with the President's commitment to cancer research. $\mathrm{Mr}$ Robert E. Sweek, a staff consultant to the panel whose experience in the planning of applied research could command a prominent role in the proposed cancer agency, is also pleased with the way things are going, although, like Mrs Lasker, he denies knowledge of whether Mr Nixon has the panel's programme in mind.

Whether or not Mr Nixon intends to set up a separate cancer agency will remain unclear probably until his message on health affairs expected next month.

Whatever the President's exact intentions, the Senate panel proposal has another influential ally in Senator Edward Kennedy who recently gained the chairmanship of the Health Subcommittee of the Senate Committee on Labor and Public Welfare. Kennedy made clear during the last session of Congress that he would introduce legislation to implement the Senate panel's proposals if he gained the chairmanship.

A distinctive feature of the new approach to cancer envisaged by the Senate panel's report is the systematic planning of research of the type that has been successful in applied research projects such as the Polaris submarine and Apollo programmes. The panel's report calls for a national crusade against cancer to proceed by four chief avenues of approach - elimination of chemical and other carcinogens, improved screening methods and the earlier detection of cancer, making present methods of cancer treatment more widely available and, fourthly, doing more research. The panel was chaired by Benno C. Schmidt, managing partner of the New York company of J. H. Whitney, and Dr Sidney Farber, director of the Boston Children's Hospital, served as co-chairman.

\section{GOVERNMENT}

\section{Advice to Advisers}

by our Washington Correspondent

AT a cautious estimate there now exist some 2,000 expert scientific committees advising federal government on technical matters ranging from the efficacy of antisubmarine devices to the safety of food additives. The invitation to serve on one of these committees is not easily turned down as it offers the chance of influencing events as well as of serving the nation. But those who follow the profession of science adviser, according to a recent study prepared at Stanford University, risk having their advice suppressed or distorted by government, their confidential knowledge turned as a weapon against outside critics, and their prestige used as an aura to hallow the government's action even when it runs directly contrary to the advice tendered. To remedy such abuses, the Stanford study proposes that the scientist accepting an advisory position should be bound by a set of guidelines to express his doubts in the open if he sees public welfare endangered by government policies of which he has expert knowledge.

Based on a set of seven case studies in which abuses of this sort are said to have 